\title{
Semi-Autonomous Control of Electric Wheelchairs using Multi-Camera Information
}

\author{
学 ○西田 貴亮 （明石高専）正関森 大介(明石高専)
}

Takaaki NISHIDA, Akashi National College of Technology, 679-3, Nishioka, Uozumi, Akashi, Hyogo Daisuke SEKIMORI, Akashi National College of Technology

1 はじめに

電動車椅子の運転には周囲の状況を見ながら常に操作す ることが強いられるため, 多くのニーザにとって大きな負 担となっている.また, その結果, 注意確認が散漫になり, 重大な事故が発生する危険性も高くなる，そこで，本研究 では，負担軽減の観点から，簡便なジョイスティック操作 量と複数のカメラ情報から走行す心゙き軌道を求めることに よって, 半自律型の走行を実現する電動車椅子を開発する.

\section{2 システム構成}

Fig.1 に開発した電動車椅子の外観とシステム構成を示 す。車椅子は市販車をベースとしており，これにパーソナ ルコンピュータ $(\mathrm{PC})$, マイクロコンピュータ $(\mathrm{MC})$, ロータ リーエンコーダ, 2 台の USBカメラが取り付けられている. 本システムのソフトウェアは Windows7 上の Microsoft Visual C++を用いて構築されており，画像処理部には OpenCV ${ }^{1)}$ の画像処理ライブラリを利用している.

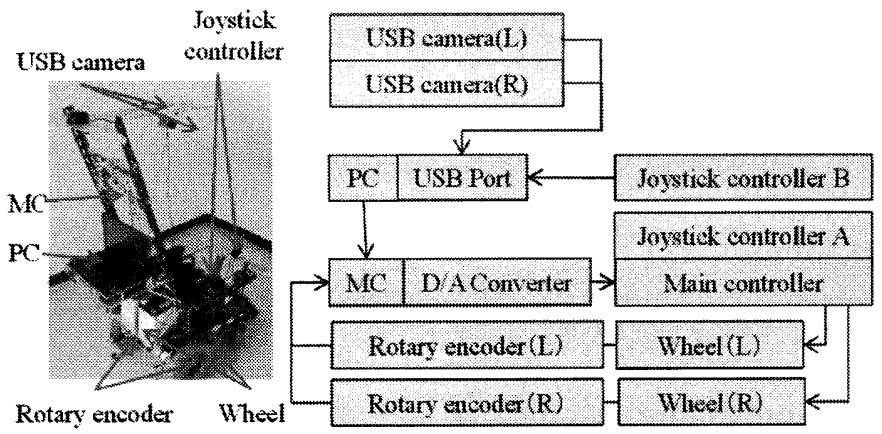

Fig1.System configuration

\section{3 半自律走行}

本研究では電動車椅子が歩道を走行することを前提とす る．この場合，歩道の縁石線から一定閒隔を保つ線を目標 軌道と定め，これを辿ることで自律走行を実現する．まず 2 つの USB カメラから得られた画像に八フ変換を施して 縁石線を抽出する．それをオフセット移動し，さらに座標 変換することで車椅子座標系における目標軌道を決定する. そして目標軌道を辿るように車椅子を制御することによっ て自律走行を実現する。

T字路や交差点のような分岐では複数の目標軌道が存在 する。この場合には，現在の目標軌道に一番近いものが選 択されて自律移動が続けられるが，別の目標軌道に变えた い場合には，その目標軌道に沿うようにジョイスティック 操作で一時的にマニュアル走行を行う。目標軌道が定まら
ない環境ではマニュアル操作のみの走行とする.

\section{4 実験および考察}

本研究の有効性を検証するために, Fig.2 に示す屋内環境 で実験を行った。まず分岐の無い通路から車椅子の自律走 行を開始し，十字路に差し掛かったところでジョイスティ ックにより一時的な入力を加えて軌道変更を行う. Fig.3に 電動車椅子の走行軌道を示寸.

結果より，分岐点での一時的なマニュアル操作のみで, 軌道変更が実現できていることが確認できた。

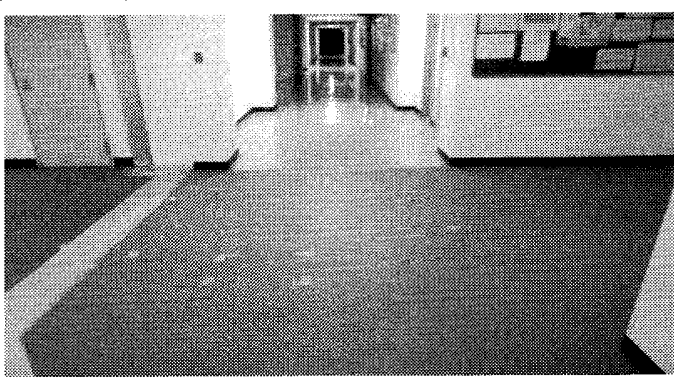

Fig2. Environment of experiments

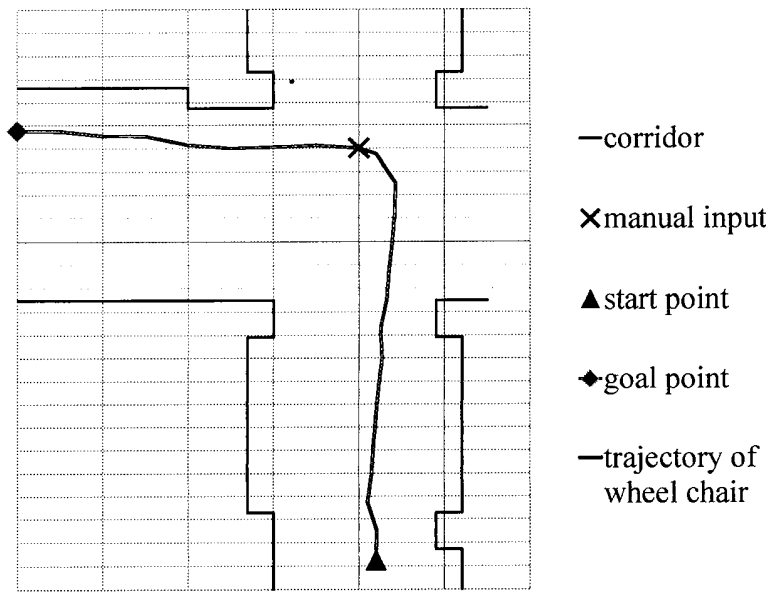

Fig3. Experimental results

\section{5 おわりに}

簡便なジョイスティック操作量と複数のカメラ情報を利 用した半自律型の電動車椅子の開発を行った。今後は複雑 な環境や移動物体が存在する環境での検証を行う予定であ る.

\section{参考文献}

1) 詳解 OpenCV ーユンピュータビジョンライブラリを使 った画像処理・認識, 2009 